\title{
INVESTOR PROTECTIONS AND CONCENTRATED OWNERSHIP: ASSESSING CORPORATE CONTROL MECHANISMS IN THE NETHERLANDS
}

\author{
ROBERT S. CHIRINKO \\ HANS VAN EES \\ HARRY GARRETSEN \\ ELMER STERKEN
}

CESIFO WORKING PAPER NO. 864

CATEGORY 9: INDUSTRIAL ORGANISATION

FEBRUARY 2003

PReSENTED AT CESIFo CONFERENCE ON THE ECONOMICS OF ORGANISATION AND CORPORATE GOVERNANCE STRUCTURES,

OCTOBER 2002

\footnotetext{
An electronic version of the paper may be downloaded

- from the SSRN website: www.SSRN.com

- from the CESifo website: www.CESifo.de
} 


\title{
INVESTOR PROTECTIONS AND CONCENTRATED OWNERSHIP: ASSESSING CORPORATE CONTROL MECHANISMS IN THE NETHERLANDS
}

\begin{abstract}
The Berle-Means problem - information and incentive asymmetries disrupting relations between knowledgeable managers and remote investors - has remained a durable issue engaging researchers since the 1930's. However, the Berle-Means paradigm - widelydispersed, helpless investors facing strong, entrenched managers - is under stress in the wake of the cross-country evidence presented by La Porta, Lopez-de-Silanes, Shleifer, and Vishny and their legal approach to corporate control.

This paper continues to investigate the roles of investor protections and concentrated ownership by examining firm behaviour in the Netherlands. Our within country analysis generates two key results. First, the role of investor protections emphasized in the legal approach is not sustained. Rather, we find that performance is enhanced when the firm is freed of equity market constraints, a result that we attribute to the relaxation of the myopia constraints imposed by relatively uninformed investors. Second, ownership concentration does not have a discernible impact on firm performance, which may reflect large shareholders' dual role in lowering the costs of managerial agency problems but raising the agency costs of expropriation.
\end{abstract}

JEL Code: G3.

Robert S. Chirinko

Department of Economics

Emory University

Atlanta, Georgia 30322-2240

U.S.A.

rchirin@emory.edu

Harry Garretsen

Utrecht School of Economics

Utrecht University

Vredenburg

1382511 BG Utrecht

The Netherlands

h.garretsen@econ.uu.nl
Hans van Ees

Department of Economics

University of Groningen

P.O.Box 800

Groningen $9700 \mathrm{AV}$

The Netherlands

h.van.ees@eco.rug.nl

Elmer Sterken

Department of Economics

University of Groningen

P.O.Box 800

Groningen $9700 \mathrm{AV}$

The Netherlands

e.sterken@eco.rug.nl 
But have we any justification for assuming that those in control of a modern corporation will also choose to operate it in the interests of the owners?

Berle and Means (1932, p. 113)

...the stockholders' position, once a controlling factor in the running of the enterprise, has declined from extreme strength to practical impotence.

Berle and Means (1932, p. 131)

\section{Introduction}

The Berle-Means problem -- information and incentive asymmetries disrupting relations between knowledgeable managers and remote investors -- has remained a durable issue engaging researchers since the 1930's. However, the Berle-Means paradigm -- widely-dispersed, helpless investors facing strong, entrenched managers -- is under stress and of only modest applicability for most developed countries. In a recent paper, La Porta, Lopez-de-Silanes, and Shleifer (LLS, 1999), examine the 20 largest firms in 27 wealthy countries, and show that concentrated ownership is the norm, not the exception. ${ }^{1}$ The Berle-Means paradigm is appropriate for the United States and United Kingdom, countries whose legal environments provide very good protection of minority shareholders' rights. LLS' cross-country results emphasize that investor protections and concentrated ownership are the key elements for understanding how the modern corporation is controlled and "how to assure financiers that they get a return on their financial investment" (Shleifer and Vishny, 1997, p. 773). ${ }^{2}$

This paper continues to investigate these two mechanisms of corporate control by examining the roles of investor protections and concentrated ownership

\footnotetext{
${ }^{1}$ See Barca and Becht (2001) and Gugler (2001) for further analysis of concentrated ownership.

${ }^{2}$ Roe (1994) presents an alternative and provocative theory of how political forces created a dispersed structure of corporate ownership in the United States. See Carney (1997) and LLS (1998, Section III) for critiques, and Roe (1999) for further elaboration of his thesis.
} 
on firm behaviour in the Netherlands. A within-country analysis complements the prior cross-country research because several factors -- taxes and regulations -- can be held constant. Dutch firms are very useful for studying these mechanisms of control because several devices exist for circumscribing investor protections that are used by many, but not all, firms. Ownership concentration also ranges widely.

The goal of this paper is to assess the impact of corporate control mechanisms on firm performance. Section II discusses the system of corporate control in the Netherlands, and reviews the roles of three key sets of actors: management and supervisory boards, shareowners, and institutions. The financial statement, anti-investor protection, and ownership data are available for 93 firms for the period 1992 to 1996. Section III discusses these data, and documents the variation in anti-investor protections and concentrated ownership in the sample. Section IV presents the estimation strategy for assessing the impact of anti-investor protections and concentrated ownership as corporate control mechanisms. We discuss the ambiguity of these control mechanisms on long-run performance (measured by the long-run return on assets computed as a five-year average), and the appropriateness of focusing on the cross-section dimension of the data.

Empirical results are contained in the next two sections. Section V contains a simple test of the substitution hypothesis between anti-investor protections and ownership concentration that is an important element in the legal approach to corporate governance. We find no support for the substitution hypothesis in our Dutch data. Rather, it seems that once anti-investor protections are in place, the firm is either avoided or abandoned by concentrated owners. Regression results are contained in Section VI. We uncover a strong positive relation between the absence of investor protections and profitability. That is, as firms are freed from the pressure of equity markets, profitability rises. No systematic relation is uncovered for ownership concentration.

A summary and conclusions are presented in Section VII. In interpreting their results presented in this paper, it is important to keep in mind that this evidence is more in the spirit of interesting conditional correlations than definitive tests about fundamental causes. The current research aims to stimulate and direct theoretical modeling that will ultimately provide the basis for more formal hypothesis testing. Thus, our empirical evidence is intended to inform views of corporate control problems and the solutions provided by various control mechanisms. 


\section{The Corporate Control System In The Netherlands}

The Dutch system of corporate control contains three key sets of actors: management and supervisory boards, shareowners, and institutions. ${ }^{3}$

\section{A. Management And Supervisory Boards}

The focal point of the corporate control system is a two-tier board structure consisting of a management board (Raad van Bestuur) in charge of the day-to-day operations of the firm and a supervisory board (Raad van Commissarissen). The supervisory board's scope of influence varies substantially depending on which organizational regime the firm adopts. The structural regime (Structuurregeling) described here applies to the majority of public limited liability companies (Naamloze Vennootschappen, NV's) listed on the Amsterdam Stock Exchange. The supervisory board has three primary functions: to appoint (usually for an indefinite term), monitor, and dismiss members of the management board (though the latter rarely occurs) ${ }^{4}$ draft the annual financial statement for presentation at the annual shareholders meeting; and approve major business decisions proposed by the management board concerning, for example, expansions, acquisitions, restructurings, or financing.

Members of the supervisory board are appointed for four year terms by cooption, that is, by the incumbent members of the supervisory board. ${ }^{5}$ An individual can not serve on both the supervisory and management boards of the same company. In practice, the management board has a very large influence on appointments to the supervisory board (van der Goot and van het Kaar, 1997). ${ }^{6}$ The

${ }^{3}$ Detailed descriptions of the system of corporate control and finance in the Netherlands can be found in CPB (1997, Chapter 10), Gelauff and den Broeder (1997), and de Jong, Kabir, Marra, and Röell (2001). We have relied particularly heavily on Gelauff and den Broeder's work in writing this section.

${ }^{4}$ Dutch management board turnover, calculated as the number of management board members leaving the firm by other than natural causes and scaled by board size, is approximately $8.0 \%$ (van Oijen, 2000). This figure is somewhat low compared to those reported for other countries; Kaplan (1994) reports turnover rates of $12.0 \%$ (excluding cases of death and illness) for the United States and 10.0\% for Germany.

${ }^{5}$ The mean [median] number of members on the supervisory and management boards for our sample of firms is 4.95 [5] and 2.95 [3], respectively.

${ }^{6}$ Inside (managerial) ownership of listed firms is unimportant in the Netherlands. Based on an ownership criterion of $5.0 \%, 19$ of 137 firms were owned by insiders sitting on the management board and an additional and different 6 firms for those on the supervisory board (de Jong et. al. (2001, Table 11). Majority ownership was achieved by the management board of 5 firms and by the supervisory board of 1 firm. For the 137 firms, average ownership is $4.86 \%$ and $1.82 \%$ for management and supervisory boards, respectively. 
two-tier board structure in the Netherlands differs substantially from that in Germany, where the supervisory board is appointed by the shareholders at the annual meeting and exerts substantial independent influence on management. The close relations between management and supervisory boards makes the Dutch twotier system somewhat similar to the U.S. system, where executive managers sit on the board of directors (comparable to the supervisory board) and the chief executive officer often chairs the board of directors. In sum, the Dutch supervisory board is largely advisory, though that counsel may receive more attention depending on the background of the advising member.

\section{B. Shareholders}

Shareholders/investors exercise control through voting at the annual meeting (Algemene Vergadering van Aandeelhouders) and, for large investors, by sitting on the supervisory board. At the annual meeting, the influence of investors is circumscribed under the structural regime in two ways. First, few important issues come before the annual meeting: the financial statement drafted by the supervisory board is voted on (amendments are not permitted), nominations for the supervisory board may be proposed and rejected, though election is by incumbent members of the supervisory board. Large investors can exert influence by refusing to approve the financial statements and supervisory board nominations.

Second and more devastating to investors' voting rights, management has available four potent devices for diluting voting power and separating control rights from cash flow rights:

-- $\quad$ Preference shares ('prefs') have the same voting rights as ordinary equity, but have a fixed payout with priority over payouts of ordinary dividends. These shares are frequently held by a continuity foundation (Stichting Continuiteit) friendly to the firm's management. Preference shares, which can be issued on a temporary basis, effectively increase the voting power of managers. This anti-investor protection (AIP(1)) is used by $66.0 \%$ of the firms in our sample.

-- $\quad$ Tradable depository receipts (TDR's) also separate cash flow and control rights. Under this procedure, the ordinary equity capital is deposited at an administrative office (Administratie-kantoor), and TDR's are issued (similar to American Depository Receipts issued on non-U.S. equity). TDR's generally entitle the holder to cash flow rights, but control rights reside with the administrative office. This anti-investor protection (AIP(2)) is used by $32.0 \%$ of the firms in our sample. 
-- $\quad$ Priority shares (Prioriteits-aandelen) carry special voting rights on matters such as "proposing or preventing the appointment of particular new members of the management and supervisory boards, approving the issue of ordinary shares, liquidation of the company or changing the articles of association" (Gelauff and den Broeder, 1997, p. 67). The issuance of priority shares curtails voting power for extant shareholders. This anti-investor protection (AIP(3)) is used by $24.0 \%$ of the firms in our sample.

In the face of these three AIP's, shareholders have little reason to pursue aggressively their limited tasks granted under the structural regime. The Dutch annual meeting differs radically from its German and U.S. counterparts, where, in principle, shareholders have a powerful effect on the course of events primarily by electing the supervisory board (or board of directors) and voting on important matters brought before shareholders.

The above AIP's all focus on altering effective voting rights by issuing shares. In considering voting rights in the Netherlands, it is important to bear in mind that investor protections and the tasks voted upon at the annual meeting are directly linked to the applicable organizational regime. Under other organizational regimes available to Dutch firms, shareholders exercise much more influence. A fourth AIP is created by the option that allows firms to choose to be governed according to the rules and regulations of the structural regime described above even if they are not required to do so by law. ${ }^{7}$

Investor protections are enhanced under the other two other legal regimes relevant to public limited liability companies. Firms that meet the criteria for the structural regime but are majority foreign-owned can follow the mitigated structural regime (Gewijzigde Structuurregeling). Under this legal regime, the supervisory board's responsibilities for appointing and dismissing members of the management board and drafting the annual financial statement are transferred to the annual shareholders meeting, enhancing investor protections. Public limited liability companies that do not meet the above criteria can adopt the common legal regime (Vennootschapsrecht) for which a supervisory board is optional. If a supervisory board is in place, appointments are determined at the annual meeting, and its only

\footnotetext{
${ }^{7}$ The majority of Dutch firms listed on the Amsterdam Stock Exchange are required to follow the structural regime because they satisfy all of the following conditions: the firm is a public limited liability company, subscribed capital exceeds 25 million guilders (approximately $\$ 12.5$ million U.S.), employment in the Netherlands exceeds 100, and employees are represented by a works council.
} 
major responsibility is to approve major management decisions. ${ }^{8}$ All other important decisions, especially the appointment of the management board, are made at the annual shareholders meeting. In sum, investor protections are substantially enhanced under the mitigated structural and common regimes, which transfer power from the supervisory board to the annual meeting. The voluntary adoption of the structural regime can thus be viewed as another device weakening investor protections because the structural regime's supervisory board is largely influenced by and hence empowers management at the expense of investors. This anti-investor protection (AIP(4)) is used by $25.0 \%$ of the firms in our sample.

\section{Institutions}

The third set of key actors in Dutch corporate governance is Institutions -financial intermediaries, workers councils, and informal networks. Financial Intermediaries also hold equity positions and, as discussed above, shareownership per se may have little impact on controlling managers. However, their equity stakes are occasionally large, and they are considered long-term, "patient" investors. Consequently, financial intermediaries frequently obtain seats on the supervisory board. ${ }^{9}$ Furthermore, banks are actively involved in extending short-term credit, and thus have a direct and potentially powerful channel of influence on management (cf. Shleifer and Vishny, 1997, Section IV.C). The role of Dutch banks is much greater than in the United States, where banks are largely prohibited from owning equity and, until very recently, were small by the standards of Continental Europe. By contrast, banks have a long-standing and prominent role on the corporate landscape in Germany where they hold large positions in both debt and equity and actively serve on, and frequently chair, supervisory boards.

Employees are represented by a Workers Council (Ondernemings-raad) that is voluntary but exists at virtually all large firms. The works council has some influence with and occasional membership on the supervisory board, where usually one member represents workers' concerns. The works council has the same rights as shareholders to propose or reject nominations to the supervisory board. The position of the works councils bear some resemblance to that played by organized labour in the United States, where union representatives frequently hold a seat on the board of directors. By contrast, legal statutes grant German workers much more

\footnotetext{
${ }^{8}$ A survey of 180 smaller limited liability companies (with 50-1000 employees) -- who were not legally obligated to install a supervisory board but did so voluntarily -- revealed that the main motive for the installation was the need for expert advice (Gelauff and den Broeder, 1997, pp. 44-45).

${ }^{9}$ Pension funds and insurance companies own more equity in the Netherlands than in Germany (13.4\% vs. 7.1\%) but much less than their U.S. counterparts (24.7\%). (Data are for 1993, and are taken from Gelauff and den Broeder, 1997, p. 46).
} 
nominal influence on corporate affairs, including between one-third to one-half of the seats on the supervisory board. ${ }^{10}$ However, the chair of the German supervisory board holds the tie-breaking vote, and this position is usually held by a person (frequently a banker) sympathetic to management's concerns.

Networks of outside board members are potentially importantly for control. These individuals hold positions on the management and supervisory boards of several companies, and/or they are "distinguished experts" drawn from the ranks of politicians, civil servants, lawyers, professors, and former directors. With their perspective and experience, these outside board members may provide valuable advice to firms.

\section{Summary}

Dutch firms are affected by a variety of different corporate control mechanisms. The extent of investor protections and concentrated ownership vary across firms, and this variation will be used in the empirical work to assess the impacts of these corporate control mechanisms on firm performance. Financial intermediaries, workers councils, and informal networks are additional control mechanisms that may also affect corporate governance and firm performance, but they will not be analyzed further in this study.

\section{The Dataset}

We draw on two sources to construct the variables used in our empirical analysis. Our sample extends from 1992-1996, unless otherwise noted. Financial statement data are obtained from the AMADEUS/REACH database covering 165 Dutch firms. We focus only on firms involved in manufacturing, omitting financial and service firms. The data will be time-averaged to form the cross-section used in the econometric work. Thus, a balanced panel is highly desirable, and we omit firms involved in mergers or takeovers. Two firms are excluded: Hunter Douglas because of erratic data and Royal Dutch Shell because it is registered in both the United Kingdom and the Netherlands. These restrictions lead to a final sample consisting of 93 firms. Variables based on financial statement data are as follows:

\footnotetext{
${ }^{10}$ German co-determination laws require that, for stock companies with 500 or more employees, onethird of the seats on the supervisory board must be held by persons elected by the employees. The fraction increases to one-half for stock companies with 2,000 or more employees.
} 

CFA $\quad=\quad$ Cash flow (operating income plus depreciation) $/ \mathrm{TA}$;
CVCFA $=$ Coefficient of variation of CFA (the standard deviation divided by the mean);
DIVERSITY $=$ The percentage of two-digit industrial activity in which the firm is involved outside its core business, measured by revenues;
LEVERAGE $=$ (TA less stockholders equity) $/ \mathrm{TA}$;
PROF $\quad=\quad$ Profitability (before-tax profits plus financial expenses) / TA;
SIZE $\quad=\quad$ The natural logarithm of TA;
TA $=\quad$ Total assets less depreciation.

For each of the 93 firms, these variables are averaged from 1992 to $1996 .^{11}$ The medians $(\mathrm{m})$, means $(\mu)$, and standard deviations $(\sigma)$ are presented in Table I.

\footnotetext{
${ }^{11}$ For those series analyzed as ratios, the ratios are computed and then summed over time; that is, ratio $=\Sigma_{\mathrm{t}}\left(\mathrm{a}_{\mathrm{i}, \mathrm{t}} / \mathrm{b}_{\mathrm{i}, \mathrm{t}}\right)$. All of the ratios are defined so that $\mathrm{b}_{\mathrm{i}, \mathrm{t}}$ is far from zero. This procedure obviates the need for price deflators, which are unavailable on a firm-specific basis.
} 


\section{TABLE I}

\section{SUMMARY STATISTICS}

The entries are the median $(\mathrm{m})$, mean $(\mu)$, and standard deviation $(\sigma)$ of the indicated variable averaged from 1992 to 1996 for each of the 93 firms. CFA is cash flow (operating income plus depreciation) / TA, where TA is total assets less depreciation; CVCFA is the coefficient of variation (the standard deviation divided by the mean) of CFA; DIVERSITY is the percentage of two-digit industrial activity in which the firm is involved outside its core business, measured by revenues; LEV is (TA less stockholders equity) / TA; OWN(L) is the ownership stake of the largest shareholder stated as a percentage of all outstanding ordinary equity; PROF is profitability (before-tax profits plus financial expenses) / TA; SIZE is the natural logarithm of TA.

\begin{tabular}{|c|c|c|c|}
\multicolumn{1}{c}{ Variable } & $\begin{array}{c}\text { Median }(\mathrm{m}) \\
(1)\end{array}$ & $\begin{array}{c}\text { Mean }(\mu) \\
(2)\end{array}$ & $\begin{array}{c}\text { Standard Deviation }(\sigma) \\
(3)\end{array}$ \\
\hline CFA & 75.636 & 406.331 & 1214.386 \\
\hline CFACV & 0.216 & 0.286 & 0.286 \\
\hline DIVERSITY & 1.700 & 1.988 & 2.052 \\
\hline LEV & 0.620 & 0.605 & 0.124 \\
\hline OWN(L) & 15.000 & 25.118 & 21.920 \\
\hline PROF & 9.072 & 9.727 & 4.775 \\
\hline SIZE & 5.972 & 6.094 & 1.655 \\
\hline
\end{tabular}

Data for anti-investor protections (AIP's) and ownership concentration (OWN's) for the firm are obtained from the Monitoring Commissie Corporate Governance (1998). The AIP's and two of the ownership variables enter as indicator variables. In those rare cases where the defining characteristic (e.g., issuing preference shares) changes over the sample, the indicator is determined by the most frequent value of the characteristic. The ownership stake $(\mathrm{OWN}(\mathrm{L}))$ is a continuous variable. The variables are defined as follows:

AIP(1) = $\quad 1$ if a firm issues preference shares;

0 elsewise.

$\mathrm{AIP}(2) \quad=\quad 1$ if the percentage of shares issued as tradable depository receipts is equal to or greater than $50.0 \%$; 0 elsewise.

$\operatorname{AIP}(3)=1$ if a firm issues priority shares;

0 elsewise.

AIP(4) $\quad=\quad 1$ if a firm is not required to implement the structural regime, but does so voluntarily;

0 elsewise. 


$\begin{array}{lll}\mathrm{OWN}(\mathrm{L}) & = & \begin{array}{l}\text { Ownership stake of the largest shareholder stated as a } \\ \text { percentage of all outstanding ordinary equity. }\end{array} \\ \mathrm{OWN}(20) & = & 1 \text { if OWN }(\mathrm{L}) \geq 0.20 ; 0 \text { elsewise. } \\ \mathrm{OWN}(40) & = & 1 \text { if } \mathrm{OWN}(\mathrm{L}) \geq 0.40 ; 0 \text { elsewise. }\end{array}$

As shown in the first row of Table II, the largest shareholder (as measured by $(\mathrm{OWN}(\mathrm{L}))$ controls more than $20 \%$ of outstanding ordinary equity for over one-half of the firms. Fifteen percent of the firms are majority owned. Table II also includes information on the distribution of the AIP's across categories of ownership concentration. The first row contains the distribution for all 93 firms, Relative to this benchmark, the different AIP's are used more or less in similar proportions.

\section{TABLE II \\ DISTRIBUTION OF ANTI-INVESTOR PROTECTIONS ACROSS LEVELS OF OWNERSHIP CONCENTRATION}

The entries are the number of firms that use a given anti-investor protection (AIP). Column 1 contains the total number of firms using a given AIP; the remaining entries in a given row distribute this total across levels of ownership concentration. All of the AIP's are indicator variables taking a value of 1 for the criteria below and zero elsewise: $\operatorname{AIP}(1)=1$ if a firm issues preference shares; $\operatorname{AIP}(2)=1$ if the percentage of shares issued as tradable depository receipts is equal to or greater than $50 \%$; $\operatorname{AIP}(3)=1$ if a firm issues priority shares; $\operatorname{AIP}(4)=1$ if a firm is not required to implement the structural regime, but does so voluntarily. See Section II.B for further discussion of the AIP's. Ownership concentration is measured by the ownership stake of the largest shareholder stated as a percentage of all outstanding ordinary equity $(\mathrm{OWN}(\mathrm{L}))$.

\begin{tabular}{|c|c|c|c|c|c|c|c|}
\hline & Number & \multicolumn{6}{|c|}{ Ownership Concentration (OWN(L)) } \\
\hline & $\begin{array}{l}\text { Of Firms } \\
\text { (1) }\end{array}$ & $\begin{array}{l}0-5 \\
(2)\end{array}$ & $\begin{array}{c}5-10 \\
\text { (3) }\end{array}$ & $\begin{array}{c}10-20 \\
\text { (4) }\end{array}$ & $\begin{array}{c}20-40 \\
(5)\end{array}$ & $\begin{array}{c}40-50 \\
(6)\end{array}$ & $\begin{array}{l}50+ \\
\text { (7) }\end{array}$ \\
\hline All Firms & 93 & 2 & 23 & 28 & 19 & 7 & 14 \\
\hline $\operatorname{AIP}(1)$ & 61 & 2 & 20 & 20 & 12 & 3 & 4 \\
\hline $\mathrm{AIP}(2)$ & 30 & 0 & 12 & 8 & 8 & 2 & 0 \\
\hline $\operatorname{AIP}(3)$ & 22 & 1 & 5 & 8 & 2 & 1 & 5 \\
\hline $\operatorname{AIP}(4)$ & 23 & 1 & 6 & 5 & 7 & 2 & 2 \\
\hline
\end{tabular}




\section{Estimation Strategy}

Our estimation strategy is to assess corporate control mechanisms by their impact on economic performance. The links between good governance and good performance are well established. As argued by Berle and Means, the incentives of managers controlling the firm differ from those of owners and, in large, publicly held corporations, most owners/investors have little incentive to expend resources to ensure that the firm is operated in their interests. Consequently, resources may be directed to activities that benefit managers rather then firm performance. Jensen (1986) has emphasized that these agency problems are likely to become particularly severe when managers have an abundance of internal resources relative to investment opportunities (i.e., "Free Cash Flow"). The important consequence is that the Berle-Means agency problem may lead the firm to a sub-optimal allocation of resources that compromise performance.

Investment decisions within the firm may also be adversely affected by undue pressure from equity investors. The "Managerial Myopia" model argues that equity markets may not allocate capital efficiently because of an absence of stable, dedicated investors with a long-term interest in the firm's performance. Formal models of strategic behaviour establish that, when inside managers know more about the firm's operations than outside owners, high hurdle rates that distort investment can occur because of a premium for signal jamming, obfuscation, or hidden action. Rather than being ameliorative, equity market pressures force management into an undue focus on boosting short-term earnings and avoiding takeover threats at the expense of long-run performance. ${ }^{12}$

In sum, agency and myopia problems adversely affect firms, and corporate control mechanisms that reduce the impact of these problems should be associated with better performance. However, as the myopia model suggests, the link between investor protections and performance is ambiguous. While a more active role for investors may mitigate agency conflicts, myopia problems may be exacerbated.

A similar ambiguity affects concentrated ownership. Concentrated ownership is a direct solution to the agency problems that arise from the separation of ownership from control. With a sufficiently large equity stake in the firm, investors have the incentive to invest resources in monitoring and disciplining managers and thus reducing agency problems. However, concentrated owners may also use their controlling position to expropriate benefits for themselves at the expense of small

\footnotetext{
${ }^{12}$ For discussions of capital allocation systems suffering from short-termism, see de Jong (1996) for the Netherlands and Porter (1992) for the United States. See Bohlin (1997) for an excellent survey of formal models of managerial incentives and investment biases.
} 
shareholders by, for example, diverting resources towards other firms in which they have substantial cash flow rights. Thus, the lower costs of managerial agency problems will be balanced against the higher agency costs of expropriation. As a result of these conflicting tendencies, the effects of AIP's and concentrated ownership on firm performance are ambiguous theoretically. Their ultimate impact is an empirical matter.

Firm performance is measured by the long-run return on assets computed as a five-year average. This computation exhausts the time dimension of our data, and thus our empirical work is based on cross-section analyses. Since the questions motivating this study focus on long-run relations among profitability and various corporate control mechanisms, focusing on the cross-section dimension of the data is appropriate. Moreover, there is very little time-series variation in the AIP's and concentrated ownership. As a consequence of the near-constancy of the corporate control variables over our sample period, we treat them as exogenous regressors. ${ }^{13}$ Finally, financial market data do not provide a good measure of the impact of corporate control variables on economic performance. In a sense, asset prices are too good a measure because they capitalize the effects of favorable/unfavorable corporate governance policies. Hence, the financial return for a firm serving shareholders' interests may differ little from the financial return for a firm with serious and unresolved corporate governance problems. The Brainard-Tobin Q is also not a useful measure because it gravitates toward its equilibrium value of unity, and it will be difficult to discern the impacts of control variables. Financial data would be useful to examine firms switching control mechanisms over time but, such time series variation and the associated event studies are not available to us in this dataset.

\section{The Substitution Hypothesis}

An important implication of the legal approach to corporate governance is that concentrated ownership substitutes for poor investor protections. This relation has been confirmed in the cross-country comparisons reported in LLSV (1998) and LLS (1999). For our within-country analysis, the comparable implication is that the AIP's will be positively correlated with ownership concentration.

Table III evaluates this hypotheses in terms of correlation coefficients for various AIP's and three measures of ownership concentration -- the value of the largest stake $(\mathrm{OWN}(\mathrm{L}))$ and indicator variables set to unity if the largest stake

\footnotetext{
${ }^{13}$ A deeper understanding of corporate control issues requires us to model the adoption of corporate control mechanisms, but this important task is not tackled in this paper.
} 
exceeds $20.0 \%(\mathrm{OWN}(20))$ or $40.0 \%(\mathrm{OWN}(40))$. There is scant evidence of a positive relation. ${ }^{14}$ Rather, in the case of preference shares or tradable depository receipts, the correlations are negative and significant at the $1.0 \%$ level. Thus, the substitution hypothesis receives little support.

TABLE III

\section{CORRELATION OF ANTI-INVESTOR PROTECTIONS AND OWNERSHIP CONCENTRATION}

The entries are the correlation coefficients between anti-investor protections (AIP's) and measures of ownership concentration (OWN's). All of the AIP's are indicator variables taking a value of 1 for the criteria below and zero elsewise: $\operatorname{AIP}(1)=1$ if a firm issues preference shares; $\operatorname{AIP}(2)=1$ if the percentage of shares issued as tradable depository receipts is equal to or greater than $50 \%$; $\operatorname{AIP}(3)=1$ if a firm issues priority shares; $\operatorname{AIP}(4)=1$ if a firm is not required to implement the structural regime, but does so voluntarily. Ownership concentration is measured by the ownership stake of the largest shareholder stated as a percentage of all outstanding ordinary equity $(\mathrm{OWN}(\mathrm{L}))$ or indicator variables, $\mathrm{OWN}(20)$ and $\mathrm{OWN}(40)$, taking a value of 1 for the criteria below and zero elsewise: $\mathrm{OWN}(20)=1$ if $\mathrm{OWN}(\mathrm{L}) \geq 0.20 ; \mathrm{OWN}(40)=1$ if $\mathrm{OWN}(\mathrm{L}) \geq$ 0.40 . For a sample of 93 firms, the critical values for the null hypothesis of no correlation are $0.170,0.201$, and 0.261 for the $10 \%, 5 \%$, and $1 \%$ significance levels, respectively. The figures in bold are those used to evaluate the substitution hypothesis.

\begin{tabular}{|c|c|c|c|c|c|c|c|}
\hline & $\begin{array}{l}\operatorname{AIP}(1) \\
(1)\end{array}$ & $\begin{array}{l}\operatorname{AIP}(2) \\
(2)\end{array}$ & $\begin{array}{l}\operatorname{AIP}(3) \\
\text { (3) }\end{array}$ & $\begin{array}{c}\operatorname{AIP}(4) \\
(4)\end{array}$ & $\begin{array}{c}\mathrm{OWN}(\mathrm{L}) \\
(5)\end{array}$ & $\begin{array}{c}\text { OWN(20) } \\
(6)\end{array}$ & $\begin{array}{c}\text { OWN(40) } \\
(7)\end{array}$ \\
\hline $\operatorname{AIP}(1)$ & 1.000 & & & & & & \\
\hline $\operatorname{AIP}(2)$ & 0.112 & 1.000 & & & & & \\
\hline $\operatorname{AIP}(3)$ & -0.023 & -0.222 & 1.000 & & & & \\
\hline $\operatorname{AIP}(4)$ & -0.005 & -0.022 & 0.033 & 1.000 & & & \\
\hline $\mathrm{OWN}(\mathrm{L})$ & -0.413 & -0.291 & 0.020 & -0.027 & 1.000 & & \\
\hline $\mathrm{OWN}(20)$ & -0.348 & -0.167 & -0.063 & 0.018 & 0.794 & 1.000 & \\
\hline OWN(40) & -0.367 & -0.263 & 0.062 & -0.071 & 0.860 & 0.635 & 1.000 \\
\hline
\end{tabular}

The above statement of the substitution hypothesis may not be sufficiently sensitive to a key maintained assumption. Who moves first: concentrated owners or management boards ${ }^{15}$ If concentrated owners move first by taking a dominant

\footnotetext{
${ }^{14}$ The reported results for AIP(2) may be biased toward a positive correlation. Under AIP(2), the percentage of shares held by an administrative office may be sufficiently large that the firm is also classified as a concentrated owner. In this case, $\operatorname{AIP}(2)$ and $\mathrm{OWN}(\mathrm{L})$ would be positively correlated, though such a correlation does not reflect a substitution of governance mechanisms. This bias does not affect the conclusion to be drawn about the substitution hypothesis in Table III.

${ }^{15}$ We thank our reviewer for highlighting the importance of these additional assumptions. .
} 
equity position, the anticipated correlation in the data would be reversed. Given that concentrated owners have an incentive to adopt good corporate governance practices, we might expect the AIP's to be eliminated. Under this scenario, ownership concentration would be negatively correlated with the AIP's.

As indicated by the analysis of the Dutch corporate governance system in Section II, management boards have a great deal of autonomy in adopting antiinvestor protections, and it appears more accurate to assume that management boards "move first." Under this assumption, two scenarios might then unfold. First, consistent with the substitution hypothesis, a firm shielded from investors by the AIP's might be very inefficient, and hence tempting for a owner to accumulate a large equity stake so that the potential efficiency gains are realized. This scenario would yield a positive correlation between AIP's and concentrated owners. Second, outside investors, regardless of the size of their equity stake, may find AIP-shielded firm undesirable. Under this scenario, potentially large shareholders would avoid and existing large shareholders would abandon the firm, and we would expect a negative correlation between the AIP's and concentrated ownership.

While simple correlations presented in Table III should not be overinterpreted, it appears that once managers compromise investor protections with AIP's, large shareholders either avoid or abandon the firm to its managers. In this initial analysis, concentrated ownership does not appear to play an ameliorative role in Dutch corporate governance.

\section{Firm Performance, Investor Protections, And Concentrated Ownership}

The roles of investor protections and concentrated ownership as corporate governance mechanisms are assessed in terms of their impact on long-run profitability. We begin our analysis by establishing a benchmark regression without any governing mechanisms but containing several conditioning variables -- the coefficient of variation of cash flow (CVCFA), a measure of the diversity of the firm's lines of business (DIVERSITY), leverage (LEVERAGE), a measure of firm size (SIZE), and seven industry dummies (not reported). ${ }^{16}$ All variables are fiveyear averages. As shown in column 1 of Table IV, only LEVERAGE is statistically significant at conventional levels (as well as most of the industry dummies), an effect that can be interpreted as reflecting the adverse effects of finance constraints in external capital markets or as a signal of maturity (since older firms tend to be both more highly levered and less profitable than younger firms).

\footnotetext{
${ }^{16}$ The explicit equation specification is presented in the notes to Tables IV-VI.
} 
TABLE IV

\section{PROFITABILITY REGRESSIONS THE ROLE OF ANTI-INVESTOR PROTECTIONS}

The parameter estimates are based on the following equation:

$$
\begin{gathered}
\text { PROF }=b_{0}+b_{1} * \text { AIP' }+b_{2} * \text { CVCFA }+b_{3} * \text { DIVERSITY } \\
+b_{4} * \text { LEVERAGE }+b_{5} * \text { SIZE }+\sum_{j} d_{j} * \text { IDUM }_{j}+e,
\end{gathered}
$$

where PROF is profitability (before-tax profits plus financial expenses) / TA, the latter defined as total assets less depreciation; AIP' is the indicated combination in Panel A of the Anti-Investor Protection variables -- AIP $(1)=1$ if a firm issues preference shares; $\operatorname{AIP}(2)=1$ if the percentage of shares issued as tradable depository receipts is equal to or greater than $50 \%$; $\operatorname{AIP}(3)=1$ if a firm issues priority shares; CVCFA is the coefficient of variation (the standard deviation divided by the mean) of CFA, the latter defined as cash flow (operating income plus depreciation) divided by TA; DIVERSITY is the percentage of two-digit industrial activity in which the firm is involved outside its core business, measured by revenues; LEVERAGE is (TA less stockholders equity) / TA; SIZE is the natural logarithm of TA; IDUM $\mathrm{I}_{\mathrm{j}}$ is a dummy for the jth industry; e is an error term. The b's and d's are estimated by ordinary least squares. Standard errors in parentheses are

\begin{tabular}{|c|c|c|c|c|c|}
\hline & (1) & $(2)$ & $(3)$ & $(4)$ & $(5)$ \\
\hline \multicolumn{6}{|l|}{ A. Anti-Investor Protections } \\
\hline $\operatorname{AIP}(1)$ or $\mathrm{AIP}(2)$ or $\mathrm{AIP}(3)$ & & $\begin{array}{c}2.408 \\
(1.241) \\
\end{array}$ & & & \\
\hline $\operatorname{AIP}(1)$ or $\operatorname{AIP}(2)$ & & & $\begin{array}{c}0.282 \\
(1.336)\end{array}$ & & \\
\hline $\operatorname{AIP}(1)$ or $\mathrm{AIP}(3)$ & & & & $\begin{array}{c}2.184 \\
(1.047)\end{array}$ & \\
\hline $\operatorname{AIP}(2)$ or $\operatorname{AIP}(3)$ & & & & & $\begin{array}{c}2.776 \\
(1.083) \\
\end{array}$ \\
\hline \multicolumn{6}{|l|}{ B. Conditioning Variables } \\
\hline Constant & $\begin{array}{r}18.409 \\
(3.596)\end{array}$ & $\begin{array}{r}16.598 \\
(3.508)\end{array}$ & $\begin{array}{c}18.142 \\
(4.347)\end{array}$ & $\begin{array}{l}17.367 \\
(3.465)\end{array}$ & $\begin{array}{r}14.678 \\
(3.544)\end{array}$ \\
\hline CVCFA & $\begin{array}{c}-0.835 \\
(2.104)\end{array}$ & $\begin{array}{c}-1.056 \\
(2.203)\end{array}$ & $\begin{array}{c}-0.865 \\
(2.171)\end{array}$ & $\begin{array}{c}-0.961 \\
(2.163)\end{array}$ & $\begin{array}{c}-0.987 \\
(2.011)\end{array}$ \\
\hline DIVERSITY & $\begin{array}{c}0.171 \\
(0.283) \\
\end{array}$ & $\begin{array}{c}0.124 \\
(0.264) \\
\end{array}$ & $\begin{array}{c}0.164 \\
(0.291) \\
\end{array}$ & $\begin{array}{c}0.104 \\
(0.266) \\
\end{array}$ & $\begin{array}{c}0.066 \\
(0.270) \\
\end{array}$ \\
\hline LEVERAGE & $\begin{array}{r}-10.609 \\
(4.408) \\
\end{array}$ & $\begin{array}{r}-9.229 \\
(4.408) \\
\end{array}$ & $\begin{array}{r}-10.339 \\
(5.046) \\
\end{array}$ & $\begin{array}{r}-9.285 \\
(4.393) \\
\end{array}$ & $\begin{array}{r}-6.058 \\
(4.497) \\
\end{array}$ \\
\hline SIZE & $\begin{array}{c}0.337 \\
(0.321) \\
\end{array}$ & $\begin{array}{r}0.243 \\
(0.330) \\
\end{array}$ & $\begin{array}{c}0.325 \\
(0.311) \\
\end{array}$ & $\begin{array}{c}0.247 \\
(0.325) \\
\end{array}$ & $\begin{array}{c}0.216 \\
(0.311) \\
\end{array}$ \\
\hline \multicolumn{6}{|l|}{ C. Statistics } \\
\hline Adjusted $\mathrm{R}^{2}$ & 0.166 & 0.197 & 0.157 & 0.196 & 0.237 \\
\hline RSS & 1.540 & 1.465 & 1.539 & 1.466 & 1.392 \\
\hline
\end{tabular}
heteroscedastic-consistent. RSS is the residual sum of squares raised to $10^{-3}$. 
The remaining entries in Table IV examine the impact of three anti-investor protections that depend on share issuance -- preference shares (AIP(1)), tradable depository receipts (AIP(2)), or priority shares (AIP(3)). We begin by allowing for the broadest possible scope for the AIP's; if a firm uses any one of these three AIP's, then a dummy variable is one. As shown in column 2, the AIP's have a substantial positive impact on firm performance that is both statistically and economically significant. In the latter regard, firms that have one or more of these AIP's are $25 \%$ more profitable than the complimentary class of firms. ${ }^{17}$ The remaining entries consider two of the AIP's at time, and the issuance of priority shares (AIP(3)) has the most consistent positive impact on profitability.

Table $\mathrm{V}$ evaluates the impact of the fourth AIP, the voluntarily adoption of the structural regime (AIP(4)). As shown in column 1, firms that transfer power away from the annual meeting to the management and supervisory boards are onethird more profitable than the average sample firm. Similar statistically significant results hold in columns 2-4, where AIP(4) is interacted with the other AIP's.

The precisely estimated and economically important positive effects of AIP's on profitability run counter to the legal approach to corporate governance. The results in Tables IV and $\mathrm{V}$ cast some doubt on the prevailing view that robust stock markets are the key to robust firm performance.

Many papers have argued that ownership concentration will attenuate agency problems. Given the wide variation in ownership concentration in the Netherlands (cf. Table II), this issue can be explored with our data. Table VI contains several specifications using different measures of ownership concentration -- the ownership stake of the largest shareholder stated as a percentage of all outstanding ordinary equity $(\mathrm{OWN}(\mathrm{L}))$ entered as a linear term, as both linear and quadratic terms or as indicator variables, OWN(20), or OWN(40). For the Dutch firms in our sample, there is little systematic relation between ownership concentration and firm performance, and little support for the proposition that ownership concentration attenuates agency problems.

${ }^{17}$ One-third of the firms in our sample do not use AIP(1), AIP(2), or AIP(3). 
TABLE V

\section{PROFITABILITY REGRESSIONS THE ROLE OF ANTI-INVESTOR PROTECTIONS}

The parameter estimates are based on the following equation:

$$
\begin{gathered}
\text { PROF }=b_{0}+b_{1} * \text { AIP' }+b_{2} * \text { CVCFA }+b_{3} * \text { DIVERSITY } \\
+b_{4} * \text { LEVERAGE }+b_{5} * \text { SIZE }+\sum_{j} d_{j} * \text { IDUM }_{j}+e,
\end{gathered}
$$

where PROF is profitability (before-tax profits plus financial expenses) / TA, the latter defined as total assets less depreciation; AIP' is the indicated combination in Panel A of the Anti-Investor Protection variables -- $\operatorname{AIP}(1)=1$ if a firm issues preference shares; $\operatorname{AIP}(2)=1$ if the percentage of shares issued as tradable depository receipts is equal to or greater than $50 \% ; \operatorname{AIP}(3)=1$ if a firm issues priority shares; $\operatorname{AIP}(4)=1$ if a firm is not required to implement the structural regime, but does so voluntarily; CVCFA is the coefficient of variation (the standard deviation divided by the mean) of CFA, the latter defined as cash flow (operating income plus depreciation) divided by TA; DIVERSITY is the percentage of two-digit industrial activity in which the firm is involved outside its core business, measured by revenues; LEVERAGE is (TA less stockholders equity) / TA; SIZE is the natural logarithm of TA; IDUM $\mathrm{j}_{\mathrm{j}}$ is a dummy for the jth industry; e is an error term. The b's and d's are estimated by ordinary least squares. Standard errors in parentheses are

\begin{tabular}{|c|c|c|c|c|}
\hline & (1) & $(2)$ & (3) & (4) \\
\hline \multicolumn{5}{|l|}{ A. Anti-Investor Protections } \\
\hline $\operatorname{AIP}(4)$ & $\begin{array}{c}3.312 \\
(1.318)\end{array}$ & & & \\
\hline $\operatorname{AIP}(4)$ and $\operatorname{AIP}(1)$ & & $\begin{array}{c}2.205 \\
(1.527)\end{array}$ & & \\
\hline $\operatorname{AIP}(4)$ and $\operatorname{AIP}(2)$ & & & $\begin{array}{c}3.788 \\
(2.113)\end{array}$ & \\
\hline $\operatorname{AIP}(4)$ and $\operatorname{AIP}(3)$ & & & & $\begin{array}{c}6.214 \\
(2.861) \\
\end{array}$ \\
\hline \multicolumn{5}{|l|}{ B. Conditioning Variables } \\
\hline Constant & $\begin{array}{l}17.626 \\
(3.309)\end{array}$ & $\begin{array}{l}18.479 \\
(3.465)\end{array}$ & $\begin{array}{c}17.850 \\
(3.567)\end{array}$ & $\begin{array}{l}17.409 \\
(2.992)\end{array}$ \\
\hline CVCFA & $\begin{array}{c}-0.325 \\
(2.093)\end{array}$ & $\begin{array}{l}-0.625 \\
(2.092)\end{array}$ & $\begin{array}{c}-0.177 \\
(2.249)\end{array}$ & $\begin{array}{c}-1.028 \\
(1.809)\end{array}$ \\
\hline DIVERSITY & $\begin{array}{c}0.068 \\
(0.281) \\
\end{array}$ & $\begin{array}{c}0.162 \\
(0.271) \\
\end{array}$ & $\begin{array}{c}0.205 \\
(0.258) \\
\end{array}$ & $\begin{array}{c}0.084 \\
(0.267) \\
\end{array}$ \\
\hline LEVERAGE & $\begin{array}{c}-10.734 \\
(4.115)\end{array}$ & $\begin{array}{c}-9.794 \\
(4.466)\end{array}$ & $\begin{array}{l}-9.375 \\
(4.529)\end{array}$ & $\begin{array}{r}-10.299 \\
(4.018)\end{array}$ \\
\hline SIZE & $\begin{array}{c}0.379 \\
(0.304)\end{array}$ & $\begin{array}{c}0.257 \\
(0.304)\end{array}$ & $\begin{array}{c}0.301 \\
(0.301)\end{array}$ & $\begin{array}{c}0.454 \\
(0.274)\end{array}$ \\
\hline \multicolumn{5}{|l|}{ C. Statistics } \\
\hline Adjusted $\mathrm{R}^{2}$ & 0.247 & 0.186 & 0.197 & 0.266 \\
\hline RSS & 1.374 & 1.485 & 1.464 & 1.338 \\
\hline
\end{tabular}
heteroscedastic-consistent. RSS is the residual sum of squares raised to $10^{-3}$. 
TABLE VI

\section{PROFITABILITY REGRESSIONS THE ROLE OF CONCENTRATED OWNERSHIP}

The parameter estimates are based on the following equation:

$$
\begin{gathered}
\text { PROF }=b_{0}+b_{1} * \text { OWN' }+b_{2} * \text { CVCFA }+b_{3} * \text { DIVERSITY } \\
+b_{4} * \text { LEVERAGE }+b_{5} * \text { SIZE }+\sum_{j} d_{j} * \text { IDUM }_{j}+e,
\end{gathered}
$$

where PROF is profitability (before-tax profits plus financial expenses) / TA, the latter defined as total assets less depreciation; OWN' is the indicated measure of concentrated ownership in Panel $\mathrm{A}$; CVCFA is the coefficient of variation (the standard deviation divided by the mean) of CFA, the latter defined as cash flow (operating income plus depreciation) divided by TA; DIVERSITY is the percentage of two-digit industrial activity in which the firm is involved outside its core business, measured by revenues; LEVERAGE is (TA less stockholders equity) / TA; SIZE is the natural logarithm of TA; IDUM $\mathrm{j}_{\mathrm{j}}$ is a dummy for the jth industry; $\mathrm{e}$ is an error term. The b's and d's are estimated by ordinary least squares. Standard errors in parentheses are heteroscedasticconsistent. RSS is the residual sum of squares raised to $10^{-3}$.

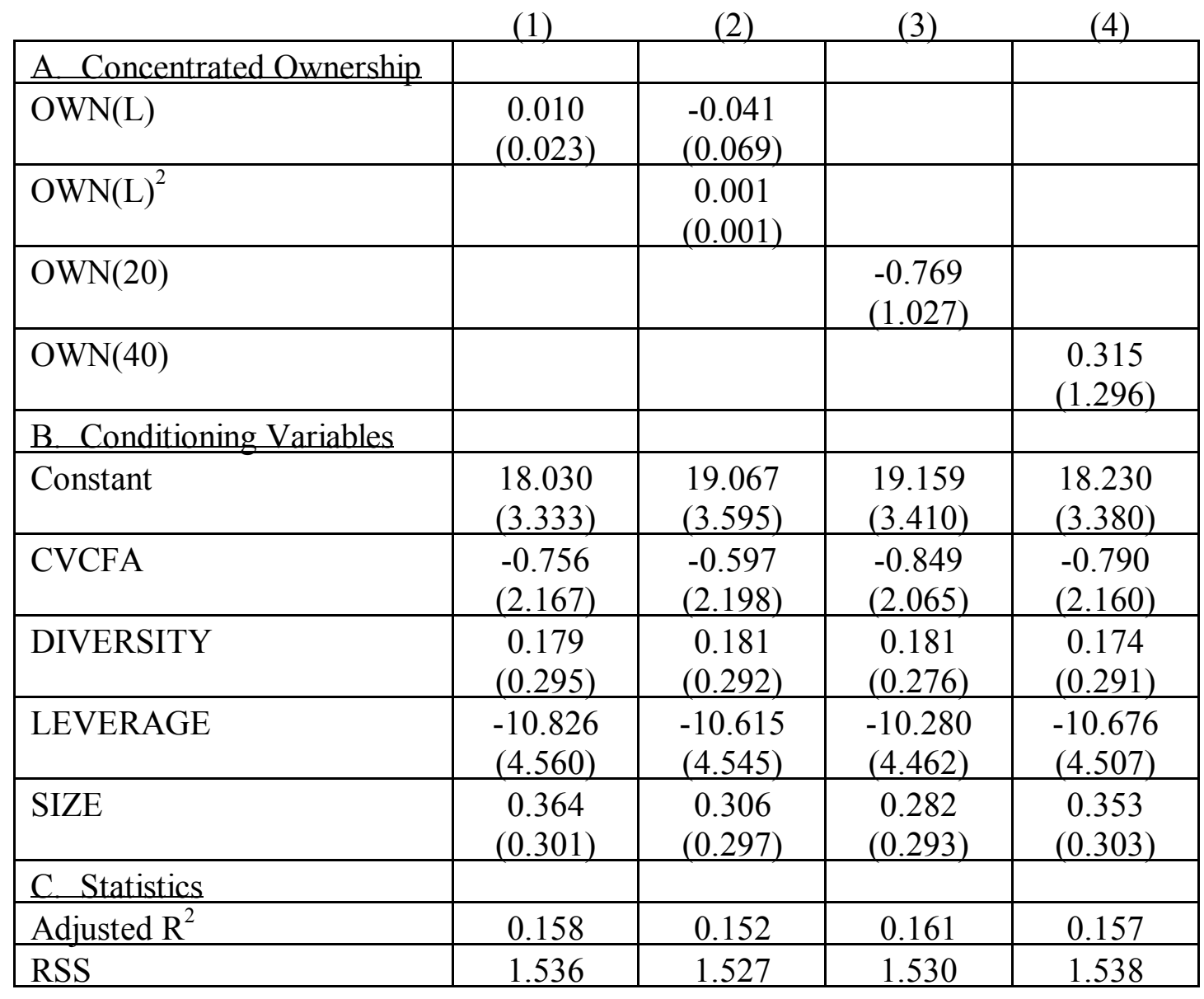




\section{Summary And Conclusions}

Recent research in corporate governance has reaffirmed the importance of the Berle-Means problem of pervasive agency problems, but has also exposed an important fault line in the Berle-Means paradigm -- the assumption of small and uninformed investors. The emerging legal approach to corporate governance highlights that the assumption of small investors is not applicable in most industrialized countries, and emphasizes the importance of investor protections and ownership concentration as complementary means for solving governance problems. To date, most of the empirical work has been cross-country.

This paper uses the interesting institutional features in the Dutch economy to undertake a within country analysis. Two key conclusions emerge. First, the role of investor protections emphasized in the legal approach is not sustained. Rather, we find that performance is enhanced when the firm is freed of equity market constraints. We attribute this to the relaxation of the myopia constraints that can be imposed by relatively uninformed investors. Second, ownership concentration does not have a discernible impact on firm performance. Our results indicate that concentrated ownership substituted with AIP's, a result consistent with potentially large shareholders avoiding or abandoning firms with anti-investor protections. In regression models of profitability, we find no systematic effect of concentrated ownership, which may reflect the tension between the lower costs of managerial agency problems versus the higher agency costs of expropriation.

These conclusions concerning investor protections and concentrated ownership should be viewed as preliminary. Two important caveats remain. First, as is well know, results for one country may not be applicable outside its borders. Second, we need a better understanding of the forces leading to the adoption of AIP's and concentrated ownership. In this study, the adoption was taken as exogenous because of the stability of the corporate control variables over our sample. Nonetheless, we would like to have a better appreciation of the forces at work influencing adoption decisions. 


\section{ACKNOWLEDGEMENT}

The authors acknowledge helpful conversations with and comments from Kees Cools, Oscar Couwenberg, George Gelauff, Leo de Haan, Niels Hermes, Rez Kabir, Huntley Schaller and from seminar participants at the American Economic Association (especially Wolfgang Eggert), CESifo Area Conference on The Economics Of Organization And Corporate Governance Structures (especially Josef Zechner), European Economic Association, Groningen, the Institute For Advanced Studies (Vienna), Tilburg, and Vienna. We thank Tutein Nolthenius Publishers for supplying data, and Emory's Institute For Comparative And International Studies and University Research Committee and Groningen's S.O.M. for partial financial support. All errors, omissions, and conclusions remain the sole responsibility of the authors. This is a revised version of CESifo Working Paper No. 210.

\section{REFERENCES}

Barca, Fabrizio, and Becht, Mario (eds.), The Control Of Corporate Europe (Oxford: Oxford University Press, 2001).

Berle, Adolf A., Jr., and Means, Gardiner C., The Modern Corporation and Private Property (New York: MacMillan, 1932). Revised edition published by Harcourt, Brace \& World in 1968.

Bohlin, Erik, "A Survey of Managerial Incentives and Investment Bias -- Common Structure but Differing Assumptions," Journal Of Business Finance \& Accounting 24 (March 1997), 197-248.

Carney, William J., "Large Bank Stockholders In Germany: Saviors Or Substitutes?," Journal of Applied Corporate Finance 9 (Winter 1997), 74-81.

CPB, Netherlands Bureau For Economic Policy Analysis, Challenging Neighbors (Heildelberg: Springer, 1997).

Gelauff, G.M.M. and den Broeder, C., Governance of Stakeholder Relationships: The German and Dutch Experience (Société Universitaire Européenne de Recherches Financières Studies No. 1 (January 1997).

Goot, L.R.T. van der, and Kaar, R.H. van het, "Beschermingsconstructies, Structuurregime En Ondernemings-waarde," Maandblad voor Accountancy en Bedrijfseconomie 71 (1997), 497-507. 
Gugler, Klaus, Corporate Governance and Economic Performance, (Oxford: Oxford University Press, 2001).

Het Financieele Dagblad, Wet Melding Zeggenschapsrecht (WMZ) (various issues).

Jensen, Michael C., "Agency Costs of Free Cash Flow, Corporate Finance, and Takeovers," American Economic Review 76 (May 1986), 323-329.

Jong, Abe de, Kabir, Rezaul, Marra, Teye, and Röell, Ailsa, "Ownership and Control in the Netherlands," in Fabrizio Barca and Mario Becht (eds.), The Control Of Corporate Europe (Oxford: Oxford University Press, 2001), 188-206.

Jong, H.W. de, "Rijnlandse Ondernemingen Presteren Beter," Economisch-Statistische Berichten 13 (March 1996), 228-232.

Kaplan, Steven N., "Top Executive Rewards And Firm Performance: A Comparison Of Japan And The United States," Journal of Political Economy 102 (1994), 510-546.

La Porta, Rafael, Lopez-de-Silanes, Florencio, and Shleifer, Andrei, "Corporate Ownership Around the World," Journal of Finance 54 (April 1999), 471-518.

La Porta, Rafael, Lopez-de-Silanes, Florencio, Shleifer, Andrei, and Vishny, Robert W., "Trust In Large Organizations," American Economic Review 87 (May 1997), 333-338.

La Porta, Rafael, Lopez-de-Silanes, Florencio, Shleifer, Andrei, and Vishny, Robert W., "Law and Finance," Journal of Political Economy 106 (December 1998), 1113-1155.

Monitoring Commissie Corporate Governance, Monitoring Corporate Governance in Nederland (Deventer: Kluwer, 1998).

Oijen, P. van, "Corporate Governance in the Netherlands," Unpublished Ph.D. Thesis, University of Amsterdam (2000).

Porter, Michael E., Capital Choices: Changing The Way America Invests In Industry (Washington: Council on Competitiveness, 1992).

Roe, Mark J., Strong Managers, Weak Owners: The Political Roots of American Corporate Finance (Princeton: Princeton University Press, 1994).

Roe, Mark J., "Political Preconditions To Separating Ownership From Control: The Incompatibility Of The American Public Firm With Social Democracy," Columbia University School of Law (1999).

Shleifer, Andrei, and Vishny, Robert W., "A Survey of Corporate Governance," Journal of Finance 52 (June 1997), 737-783. 


\section{CESifo Working Paper Series}

(for full list see www.cesifo.de)

798 Mariam Camarero, Javier Ordóñez, and Cecilio Tamarit, The Euro-Dollar Exchange Rate: Is it Fundamental?, October 2002

799 Misa Tanaka, How Do Bank Capital and Capital Adequacy Regulation Affect the Monetary Transmission Mechanism?, October 2002

800 Jörg Baten and Andrea Wagner, Autarchy, Market Disintegration, and Health: The Mortality and Nutritional Crisis in Nazi Germany, 1933-1937, October 2002

801 Saku Aura, Uncommitted Couples: Some Efficiency and Policy Implications of Marital Bargaining, October 2002

802 Wolfram F. Richter, Delaying Integration of Immigrant Labor for the Purpose of Taxation, October 2002

803 Gil S. Epstein and Shmuel Nitzan, The Politics of Randomness, October 2002

804 John Hassler and José V. Rodriguez Mora, Should UI Benefits Really Fall over Time?, October 2002

805 Friedrich Breyer and Stefan Felder, The Dead-anyway Effect Revis(it)ed, October 2002

806 Assar Lindbeck and Solveig Wikström, E-exchange and the Boundary between Households and Organizations, November 2002

807 Dieter Bös, Contests Among Bureaucrats, November 2002

808 Steven Brakman, Harry Garretsen, and Marc Schramm, The Strategic Bombing of German Cities during World War II and its Impact on City Growth, November 2002

809 Florian Englmaier and Achim Wambach, Contracts and Inequity Aversion, November 2002

810 Sarbajit Sengupta, Delegating Recruitment under Asymmetric Information, December 2002

811 Rajshri Jayaraman, On the Partial Public Provision of a Private Good, December 2002

812 Stéphanie Stolz, Banking Supervision in Integrated Financial Markets: Implications for the EU, December 2002

813 Christian Keuschnigg, Taxation of a Venture Capitalist with a Portfolio of Firms, December 2002 
814 Inés Macho-Stadler and David Pérez-Castrillo, Settlement in Tax Evasion Prosecution, December 2002

815 Rainer Niemann and Dirk Simons, Costs, Benefits, and Tax-induced Distortions of Stock Option Plans, December 2002

816 Jan-Egbert Sturm and Barry Williams, Deregulation, Entry of Foreign Banks and Bank Efficiency in Australia, December 2002

817 V. Anton Muscatelli, Patrizio Tirelli, and Carmine Trecroci, Monetary and Fiscal Policy Interactions over the Cycle: Some Empirical Evidence, December 2002

818 Claude Hillinger, A General Theory of Price and Quantity Aggregation and Welfare Measurement, December 2002

819 Erkki Koskela and Ronnie Schöb, Optimal Capital Taxation in Economies with Unionised and Competitive Labour Markets, December 2002

820 Sheilagh Ogilvie, Guilds, Efficiency, and Social Capital: Evidence from German ProtoIndustry, December 2002

821 Hans Gersbach and Verena Liessem, Financing Democracy, December 2002

822 Costas Hadjiyiannis, Panos Hatzipanayotou, and Michael S. Michael, Optimal Tax Policies with Private-Public Clean-Up, Cross-Border Pollution and Capital Mobility, December 2002

823 François Ortalo-Magné and Sven Rady, Homeownership: Low Household Mobility, Volatile Housing Prices, High Income Dispersion, December 2002

824 Syed M. Ahsan and Panagiotis Tsigaris, Measuring the Social Discount Rate under Uncertainty: A Methodology and Application, December 2002

825 Kai A. Konrad, Altruism and Envy in Contests: An Evolutionarily Stable Symbiosis, December 2002

826 Robert S. Chirinko and Huntley Schaller, A Revealed Preference Approach to Understanding Corporate Governance Problems: Evidence from Canada, December 2002

827 Geir B. Asheim, Green National Accounting for Welfare and Sustainability: A Taxonomy of Assumptions and Results, December 2002

828 Andrea Gebauer, Chang Woon Nam, and Rüdiger Parsche, Lessons of the 1999 Abolition of Intra-EU Duty Free Sales for Eastern European EU Candidates, December 2002

829 Giacomo Corneo, Work and Television, December 2002

830 Vivek H. Dehejia and Yiagadeesen Samy, Trade and Labour Standards - Theory, New Empirical Evidence, and Policy Implications, December 2002 
831 Geir B. Asheim and Wolfgang Buchholz, A General Approach to Welfare Measurement through National Income Accounting, December 2002

832 Aaron Tornell and Frank Westermann, The Credit Channel in Middle Income Countries, January 2003

833 Gebhard Flaig, Time Series Properties of the German Monthly Production Index, January 2003

834 Campbell Leith and Jim Malley, Estimated Open Economy New Keynesian Phillips Curves for the G7, January 2003

835 Burkhard Heer and Bernd Süssmuth, Inflation and Wealth Distribution, January 2003

836 Erkki Koskela and Leopold von Thadden, Optimal Factor Taxation under Wage Bargaining - A Dynamic Perspective, January 2003

837 Carola Grün and Stephan Klasen, Growth, Income Distribution, and Well-Being: Comparisons across Space and Time, January 2003

838 Robert S. Chirinko and Ulf von Kalckreuth, On the German Monetary Transmission Mechanism: Interest Rate and Credit Channels for Investment Spending, January 2003

839 Sascha O. Becker, Andrea Ichino, and Giovanni Peri, How Large is the "Brain Drain" from Italy?", January 2003

840 Albert Berry and John Serieux, All About the Giants: Probing the Influences on Growth and Income Inequality at the End of the $20^{\text {th }}$ Century, January 2003

841 Robert Fenge and Martin Werding, Ageing and the Tax Implied in Public Pension Schemes: Simulations for Selected OECD Countries, January 2003

842 Robert Fenge and Martin Werding, Ageing and Fiscal Imbalances Across Generations: Concepts of Measurement, January 2003

843 Giovanni Andrea Cornia, The Impact of Liberalisation and Globalisation on Income Inequality in Developing and Transitional Economies, January 2003

844 Peter Fredriksson and Per Johansson, Program Evaluation and Random Program Starts, January 2003

845 Bernd Hayo and Matthias Wrede, Fiscal Equalisation: Principles and an Application to the European Union, January 2003

846 Syed M. Ahsan and Jaideep Oberoi, Inequality, Well-being and Institutions in Latin America and the Caribbean, January 2003

847 Chang Woon Nam and Doina Maria Radulescu, The Role of Tax Depreciation for Investment Decisions: A Comparison of European Transition Countries, January 2003 
848 V. Bhaskar and Steinar Holden, Wage Differentiation via Subsidised General Training, January 2003

849 Paloma Lopez-Garcia, Labour Market Performance and Start-up Costs: OECD Evidence, January 2003

850 Christian Keuschnigg and Soren Bo Nielsen, Public Policy for Start-up Entrepreneurship with Venture Capital and Bank Finance, January 2003

851 Yin-Wong Cheung, Menzie D. Chinn, and Eiji Fujii, China, Hong Kong, and Taiwan: A Quantitative Assessment of Real and Financial Integration, January 2003

852 Gregory D. Hess, The Economic Welfare Cost of Conflict: An Empirical Assessment, February 2003

853 Douglas J. Cumming and Jeffrey G. MacIntosh, Comparative Venture Capital Governance. Private versus Labour Sponsored Venture Capital Funds, February 2003

854 Eckhard Janeba and John Douglas Wilson, Decentralization and International Tax Competition, February 2003

855 Tapio Palokangas, Capital Accumulation and Employment Cycles in a Model of Creative Destruction, February 2003

856 Brendan Walsh, When Unemployment Disappears: Ireland in the 1990s, February 2003

857 Luis H. R. Alvarez and Erkki Koskela, A General Approach to the Stochastic Rotation Problem with Amenity Valuation, February 2003

858 Christian Schultz, Strategic Campaigns and Redistributive Politics, February 2003

859 Ernst Fehr and Joseph Henrich, Is Strong Reciprocity a Maladaptation? On the Evolutionary Foundations of Human Altruism, February 2003

860 Haizhou Huang, Dalia Marin, and Chenggang Xu, Financial Crisis, Economic Recovery and Banking Development in Former Soviet Union Economies, February 2003

861 Pedro Cardoso and Bernard M.S. van Praag, How Sustainable Are Old-age Pensions in a Shrinking Population with Endogenous Labour Supply?, February 2003

862 Volker Meier, Efficient Transfer of Aging Provisions in Private Health Insurance, February 2003

863 Edward Castronova, Theory of the Avatar, February 2003

864 Robert S. Chirinko, Hans van Ees, Harry Garretsen, and Elmer Sterken, Investor Protections and Concentrated Ownership: Assessing Corporate Control Mechanisms in the Netherlands, February 2003 